\title{
55. A critical inquiry into in-service EFL teachers' intercultural self-efficacy beliefs and experiences
}

\section{Zeynep Gülşah KANí1}

\section{Seda YILMAZTÜRK²}

\begin{abstract}
APA: Kani, Z. G.; Yılmaztürk, S. (2021). A critical inquiry into in-service EFL teachers' intercultural self-efficacy beliefs and experiences. RumeliDE Dil ve Edebiyat Araştırmaları Dergisi, (23), 875893. DOI: 10.29000/rumelide.949723.
\end{abstract}

\begin{abstract}
This paper examines the intercultural self-efficacy beliefs and experiences of university EFL teachers from socially and linguistically diverse backgrounds working at English language preparatory schools in İstanbul. Adopting a mixed-methods case study design under a critical interpretivist theoretical framework, the study included both quantitative and qualitative data collected through an intercultural self-efficacy beliefs and experiences scale and via interviews with interculturally experienced participants from Turkish, Western and Middle Eastern backgrounds. Descriptive statistical and thematic analyses revealed that the teachers had intercultural experiences mostly in their workplaces and that they developed positive attitudes toward diversity in the classroom though they were concerned about intercultural language teaching in practice due to the time constraint. The teachers highlighted some of the features that could be regarded as a part of having intercultural competence: being respectful and willing to communicate with diverse people, accepting diversity, discussing the different and unknown, and displaying humour. Their accounts of intercultural experiences were indicative of a complex, layered and overlapping view of culture influenced by several discourses, the most frequently referred ones of which were 'individualism' and 'collectivism'. In the light of the study, we offer implications and new insights into 'non-monocentric' cultural threads through the eyes of language teachers as one of the key actors in classrooms, where local praxes and discourses may have more impact than national or international ones.
\end{abstract}

Keywords: Culture, identity, discourse, intercultural studies, in-service EFL teachers

\section{Hizmet içi İngilizce öğretmenlerinin kültürlerarası öz-yeterlik inançları ve deneyimleri üzerine eleştirel bir araştırma}

\section{$\ddot{O} \mathbf{z}$}

Bu makale, İstanbul'daki İngilizce hazırlık okullarında çalışan, sosyal ve dilsel olarak farklı geçmişlere sahip üniversite İngilizce öğretmenlerinin kültürlerarası öz-yeterlik inançlarını ve deneyimlerini incelemektedir. Eleştirel yorumlayıcı bir kuramsal çerçeve altında karma yöntemli bir vaka çalışması tasarımını benimseyen çalışma, kültürlerarası öz-yeterlik inançları ve deneyimleri ölçeği aracılığıyla ve Türk, Batı ve Orta Doğu kökenli kültürlerarası tecrübeli katılımcılarla yapılan görüşmeler yoluyla toplanan hem nicel hem de nitel verileri içermektedir. Betimsel istatistiksel ve

Dr. Öğr. Üyesi, Çanakkale Onsekiz Mart Üniversitesi, Eğitim Fakültesi, Yabancı Diller Eğitimi Bölümü, İngilizce Eğitimi ABD (Çanakkale, Türkiye), zgulsahkani@gmail.com, ORCID ID: oooo-0002-1316-0658 [Araştırma makalesi, Makale kaylt tarihi: 16.04.2021-kabul tarihi: 20.06.2021; DOI: 10.29000/rumelide.949723]

Öğr. Gör., Istanbul Gelişim Üniversitesi, Yabancı Diller Yüksekokulu, Ölçme ve Değerlendirme Birimi (İstanbul, Türkiye), syilmazturk@gelisim.edu.tr, ORCID ID: 00oo-0002-2485-2326

Adres $\mid$ Address

RumeliDE Dil ve Edebiyat Araştırmaları Dergisi $\quad$ RumeliDE Journal of Language and Literature Studies Osmanağa Mahallesi, Mürver Çiçeği Sokak, No:14/8 Osmanağa Mahallesi, Mürver Çiçeği Sokak, No:14/8

Kadıköy - İSTANBUL / TÜRKIYE 34714 Kadıköy - ISTANBUL / TURKEY 34714 e-posta: editor tel: +90 505 7958124, +90 2167730616

e-mail: editor@rumelide.com

phone: +90 5057958124 , +90 2167730616 
A critical inquiry into in-service EFL teachers' intercultural self-efficacy beliefs and experiences / Z. G. Kani; S. Yllmaztürk (pp. 875-893)

tematik çözümlemeler öğretmenlerin daha çok işyerlerinde kültürlerarası deneyimler yaşadıklarını ve zaman kısıtlaması nedeniyle uygulamada kültürlerarası dil öğretimine ilişkin endişe duymalarına rağmen sınıfta çeşitliliğe karşı olumlu tutumlar geliştirdiklerini ortaya koymuştur. Öğretmenler kültürlerarası yeterliliğe sahip olmanın bir parçası olarak görülebilecek bazı özellikleri vurguladılar: saygılı ve çeşitli insanlarla iletişim kurmaya istekli olmak, çeşitliliği kabul etmek, farklı ve bilinmeyeni tartışmak ve mizah sergilemek. Kültürlerarası deneyimlerle ilgili açıklamaları, en sık atıfta bulunulanı 'bireycilik' ve 'toplumculuk' olan çeşitli söylemlerden etkilenen karmaşık, katmanlı ve iç içe geçen bir kültür görüşünün göstergesiydi. Çalışmanın ışığında, yerel uygulamaların ve söylemlerin ulusal ya da uluslararası olanlardan daha fazla etkiye sahip olabileceği sınıflarda, anahtar oyunculardan biri olarak dil öğretmenlerinin gözünden, 'tekmerkezci olmayan' kültürel konulara ilişkin çıkarımlar ve yeni içgörüler sunuyoruz.

Anahtar kelimeler: Kültür, kimlik, söylem, kültürlerarası çalışmalar, hizmet içi İngilizce öğretmenleri

\section{Introduction}

Successful communication could be achieved not only by means of linguistic knowledge but also through an understanding of different historical, social and cultural contexts. In the varied contexts of English use(s), it is urgent to approach culture as an emergent, complex, and moving entity between and across local and global settings. There have been different approaches to intercultural communication within English language teaching, depending on how culture and communication are viewed. It is well known that everyone perceives the world differently and that the language they use influences their perceptions. In other words, language symbolises and creates culture at the same time. While the relationship between these concepts has been discussed according to different perspectives, a more critical understanding of culture has prevailed in the last two decades. A number of researchers (House, 2002; Phipps \& Guilherme, 2005; Kirkpatrick, 2007; Holliday, 2011; Yulita, 2013; Nugent and Catalano, 2013) have highlighted that language is not culturally neutral. In intercultural communication, every individual has their own purposes and cultural identities, and these ideological dimensions of communication cannot be ignored. In this critical perspective, therefore, culture and language are described as emergent and dynamic entities. Moreover, boundaries between culture and language are less delineated, as the use of English in local and global settings is believed to create constant and dynamic change (Baker, 2011).

While local and global settings are crucial in terms of the individual's understanding of culture, English language teachers in such settings are the key role models who could establish an interculturally sensitive language teaching context by introducing different points of view to their students. Hence, there has been a spurring interest in exploring language teachers' (inter)cultural awareness and intercultural language teaching beliefs through mostly competency-based frameworks in the literature (see section 1.2 for a review). Nevertheless, there is a growing need for more in-depth, situated and contextualised mixed-methods studies as complementary to the use of competency-based models, which are found to be restrictive as they do not uncover ideologies and context-specific discourses (Holliday, Hyde \& Kullman, 2010).

One of the goals of critical cultural awareness is to reveal the ideologies that learners have and provide them with opportunities to critically evaluate these ideologies which may cause intercultural conflicts in communication (Yulita, 2013). Moreover, as Nugent and Catalano (2013) propose, educators must

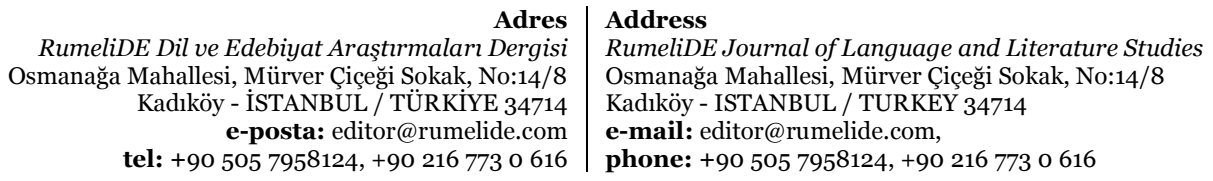


scaffold learners through developmentally important practices which lead them to reflect on their prejudiced ideas, stereotypes, and judgements about intercultural contexts in line with the spread of English use(s). These suggestions deserve considerable attention since the use of English as an international language has brought the need for an in-depth understanding of cultural contexts in communication and forces educators to think beyond the specific and fixed notions of cultural discourses. Therefore, in this mixed-methods study, with an understanding of different perspectives on intercultural communication, we adopt a more critical and non-essentialist position of culture which is fluid and blended with different interhuman exchanges beyond the knowledge of specific 'cultures' and beyond the clear division of 'our' culture and 'their' culture at the centre of competencybased models. After drawing on the related frameworks about culture and intercultural communication in relation to language learning and teaching, we will review intercultural studies on English language teachers' beliefs, attitudes, and experiences around the world and in Turkey.

\section{Different perspectives on culture}

There have been changing perspectives of culture in language learning and teaching processes throughout the years. Kramsch (2013) concludes that there are two main cultural perspectives in language teaching: modernist and postmodernist perspectives. In the modernist perspective, he mainly discusses 'Big C culture' and 'Little c culture'. The 'Big C' culture is regarded to be about literature, history, and institutions, which are aimed to be promoted by schools as national heritage to the learners (Kramsch, 2013). Indeed, it has got a nation-related aspect which is also closely related to the moral values. However, he criticises it since students are equipped with stereotypes of foreign 'cultures' in this way. Unlike the 'Big C' culture, the 'Little c' culture, which is also called as 'small cultures' by Holliday (1999), has been described with a focus on communication and interaction in social settings. In this regard, not only visible elements of culture such as history, art, and literature, but also speakers' everyday actions are to be integrated and interpreted in the learning process. Kramsch (2013) highlights the belief of 'one language is one culture' among language teachers and states that while teaching the rules of grammar, they are also requested to include the rules of sociolinguistic use of language. It is also criticised as this concept of teaching focuses on native speakers' acts as culture and still highlights stereotypes, typical customs, and the beliefs of native speakers with the lack of in-depth understanding.

Along with the globalised world, the nation-oriented perspective of culture as definable common beliefs and values between different communities has evolved into a more multi-layered and dynamic perspective as a result of the understanding of shared practices. Kramsch (2013) stresses the fact that the interpretation of incidents may change according to the interactions with others constantly. Therefore, he defines culture as a dynamic and discursive entity which is not restricted to boundaries of nations from the postmodernist perspective of culture regarded as a social semiotic construction.

Similarly, Holliday (2011) criticises culture if it is viewed from an essentialist perspective, which classifies individuals' behaviours depending on their 'cultures' in which they live. In this view, nation plays a great role in individuals' 'cultures' as physical territories. Thus, the essence of who they are is believed to be shaped by the stereotypes which come out in many predetermined beliefs. However, Holliday (2011) argues that although the role of nation is inevitable, it is not the only source of cultural information, and that there are a variety of underlying factors for every individual. He also states that even though intercultural studies criticise the essentialist views, they still rely on this perspective and end up with neo-essentialism, in which nation-based culture still forms the main view in defining

\footnotetext{
RumeliDE Dil ve Edebiyat Araşttrmaları Dergisi Osmanağa Mahallesi, Mürver Çiçeği Sokak, No:14/8 Kadıköy - İSTANBUL / TÜRKIYE 34714 e-posta: editor@rumelide.com tel: +90 505 7958124, +90 2167730616

Address

RumeliDE Journal of Language and Literature Studies Osmanağa Mahallesi, Mürver Çiçeği Sokak, No:14/8

Kadıköy - ISTANBUL / TURKEY 34714

e-mail: editor@rumelide.com,

phone: +90 5057958124 , +90 2167730616
} 
culture even if diversity is accepted on the surface. In the intercultural context, there is still a concern of comparing 'our' culture with 'their' culture. On the other hand, critical cosmopolitanism, a postmodernist perspective, does not accept these certainties and attempts to show the complexity of the unequal world that is affected and shaped by ideologies. Critical cosmopolitanism views culture from a non-essentialist perspective. It asserts that culture is complex, and it does not have certain boundaries as in the essentialist view. Diversity is believed to play the key role in cultural realities. Unlike the essentialist perspective, it draws attention to the inequality between Centre-Periphery and adopts a more interpretivist view.

With the shifts in the view of English use(s) from Centre to Periphery, there has also been a call for moving towards a more inclusive and interculturally sensitive English language teaching (ELT) (Liddicoat \& Scarino, 2013; Newton et al., 2010; Witte, 2014). After a discussion of a range of cultural perspectives in consideration of pursuing this call, we turn to a review of intercultural studies in the literature, with different approaches to cultural realities.

\section{Intercultural studies in international and local contexts}

With the globalisation and advances in technology, the world has become a smaller place, and this brings closer relationships among diverse cultural communities and individuals than ever. Therefore, in recent years, there has been an interest in intercultural communication in ELT. A considerable amount of literature has been published on intercultural language teaching studies all around the world. These studies mainly include intercultural communication competence (ICC) models.

A bulk of research have been reported on teacher's intercultural language teaching beliefs (Altan, 2018; Arcagök and Yılmaz, 2020; Atay et al., 2009; Beutel and Tangen, 2018; Kaça, 2015; ÇetinKöroğlu, 2016; Çubukçu, 2013; Demircioğlu \& Çakır, 2015; Ersoy, 2013; Hayden, Rancic \& Thompson, 2000; Israelsson, 2016; Keranen \& Bayyurt 2006; Lázár, 2011; Lin, 2018; Oranje and Smith, 2018; Polat \& Ogay-Barka, 2014; Sercu, 2005, 2006; Smolcic \& Arends, 2017; Türkyılmaz-Sinclair, 2019; Young and Sachdev, 2011). To start with, Beutel and Tangen (2018) researched the impact of intercultural experiences on shaping pre-service teachers' preparedness to engage with diverse students in Australia and found a positive relationship between the variables. Hayden et al. (2000) investigated the characteristics of being 'international' from the teachers' and 18-year-old students' perspectives. The results showed that being international in general means international mindedness, thinking flexibly, respecting others and showing tolerance. Similarly, Demircioğlu \& Çakır (2015) explored the intercultural competence of language teachers by comparing Turkey and countries such as the UK, the USA, New Zealand, and Spain. It was concluded that all the teachers thought intercultural language teaching was crucial due to globalisation and that ICC had to be included in language teaching. Most of the teachers considered that ICC was more significant than linguistic competence. Teachers also reported that the adoption of intercultural teaching provided positive changes in students' intercultural competence. In Sweden, Israelsson (2016) examined the interpretation of the concept of IC by six English teachers at upper secondary schools for adults through semi-structured interviews, and suggested that they lacked theoretical background and central guidance regarding the integration of IC into the ELT pedagogy.

Lázár (2011) inquired two Hungarian pre-service English teachers' beliefs about their role in the ICC development, and the factors that influenced their beliefs. Lin (2018) also examined pre-service teachers' intercultural development with the participation in a pen-pal project. The participants who

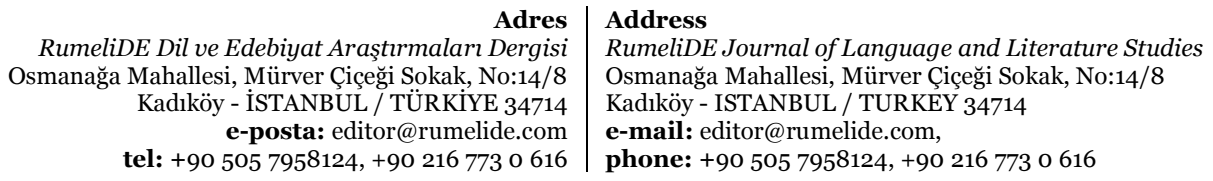


were from the USA were paired with Turkish pre-service teachers. After the project, they reported that they developed an intercultural competence and gathered an understanding about their pen pals' 'cultures', and were able to compare and contrast the similarities and differences of these 'cultures'. While it was noted that not all of them were able to realise learning and teaching were affected by ideologies such as societal norms and politics, they could engage in internalised dialogue. Like Lin (2018), Smolcic \& Arends (2017) explored the perspectives of pre-service teachers' intercultural learning and their reflections about it. The findings of the study showed that the pre-service teachers showed cultural self-awareness, awareness of the complexity of cultural identity, empathy, and emerging critical cultural awareness.

Sercu (2006) conducted an international study into teachers' willingness to teach ICC in Belgium, Bulgaria, Greece, Mexico, Poland, Spain and Sweden, and found that they had an overall positive disposition. However, she reported that there was a discrepancy between their beliefs and practices (Sercu, 2005). Similarly, Oranje and Smith (2018) administered a questionnaire to reveal the relationship between teacher beliefs and practices related to intercultural language teaching (ILT) in New Zealand, and reported an apparent mismatch between beliefs and practices, with teachers being positively disposed towards ILT, albeit not practising the approach in their classrooms. Young and Sachdev (2011) also confirmed the results of the studies indicating a mismatch between classroom priorities and beliefs about ICC due to little emphasis in international syllabi, in testing, and in textbooks.

In the Turkish context, similar to the aforementioned studies, more recently, Çetin-Köroğlu (2016), Altan (2018), Türkyılmaz-Sinclair (2019) and Arcagök and Yllmaz (2020) identified various codes regarding the intercultural sensitivities of Turkish pre-service EFL teachers. The latest cited one associated a high level of ICC with voluntary work in a non-governmental organisation. Keranen \& Bayyurt (2006) examined how Turkish pre-service EFL teachers and Mexican in-service EFL teachers communicate about their 'cultures' and their reflections about different cultural exchanges. The researchers explored the building of intercultural awareness through telecollaboration. The study reported that students seemed to show some kind of cultural understanding, yet the researchers were concerned about the superficiality of culture learning. Similarly, Çubukçu (2013) investigated the intercultural sensitivity among pre-service teachers and revealed that they gave importance to showing sympathy and tolerance for others. Moreover, pre-service teachers were found to be eager to attain culture learning aims into their teaching practices and curriculum. Likewise, Polat and Ogay-Barka (2014) investigated Turkish and Swiss pre-service teachers' intercultural competence levels. It was a comparative study, and the findings revealed that pre-service teachers from Switzerland had higher intercultural competence than pre-service teachers in Turkey. However, all of them were found to be most competent in showing cultural empathy, flexibility, open-mindedness, social initiative. Furthermore, Ersoy (2013) examined Turkish teacher candidates' cross-cultural experiences through the Erasmus exchange program and found out that they faced some problems regarding cultural differences, and about the language use in the countries they visited. The findings showed that the teacher candidates understood the importance of learning the English language, and of learning about cultural differences and thus, the importance of cultural awareness.

Atay et al. (2009) revealed that EFL teachers had positive attitudes towards the development of the ICC, while in practice they did not often integrate cultural elements into their teaching. In a similar vein, Kaça (2015) conducted a more multi-faceted study into EFL instructors' beliefs and practices of cultural content in the ELT classroom through the English as an international language lens. He used a

\footnotetext{
\begin{tabular}{r|l} 
Adres & Address \\
RumeliDE Dil ve Edebiyat Araşttrmaları Dergisi & RumeliDE Journal of Language and Literature Studies
\end{tabular} Osmanağa Mahallesi, Mürver Çiçeği Sokak, No:14/8 Osmanağa Mahallesi, Mürver Çiçeği Sokak, No:14/8 Kadıköy - İSTANBUL / TÜRKIYE 34714 Kadıköy - ISTANBUL / TURKEY 34714 e-posta: editor@rumelide.com e-mail: editor@rumelide.com, tel: +90 505 7958124, +90 2167730616 phone: +90 505 7958124, +90 2167730616
} 
case study research design including the use of a questionnaire on their beliefs, the observation of classroom practices and interviews, and found out that most of the teachers regarded teaching culture vital in ELT for its potential as a motivational tool to communicate with 'native' speakers of English rather than for its value of paving the way for intercultural communication. On the contrary, in practice, specific external factors such as the exam-oriented system and curricular restraints prevented them from including such cultural elements in the classroom.

Despite a considerable amount of research relating to intercultural communication and beliefs, not many studies have been published from a critical intercultural communication perspective in the Turkish context. In this vein, more attention needs to be paid to in-service teachers' intercultural selfefficacy beliefs and experiences through a multi-faceted lens and beyond competency-based models. Therefore, the aim of the present study is to investigate both the intercultural beliefs and experiences of in-service teachers by making thick descriptions from a critical perspective. In line with this aim, the study seeks to address the following research questions:

RQ1. What are the intercultural self-efficacy beliefs and experiences of in-service English language teachers at universities?

RQ2. What insights can we gain into their views of culture and identity in relation to their intercultural exchanges?

\section{Methodology}

\section{Research design}

The present research has been designed as a descriptive case study. Case studies attempt to portray what is happening in a particular situation by especially giving emphasis on thick descriptions of participants' experiences, feelings and ideas about incidents (Geertz , 1973). They are both detailed and descriptive, blending objective and subjective data (Dyer, 1995). The events and situations have been spoken by participants themselves; however, what they have stated about incidents are evaluated and interpreted by the researcher's point of view. In this respect, the current research attempts to show an in-depth analysis of participants' both beliefs and experiences on intercultural communication. As Holliday (2011) proposes, while presenting the findings, critical interpretivism has been employed in this research to display the hidden aspects of participants' beliefs through thick descriptions. Thick descriptions attempt to investigate the big picture to see the unexpressed, and it goes deeper to analyse. It is described as the analysis of all the aspects of the social discourse by focusing on its complexity. It enables us to make meaning of the incidents and find the hidden and suspend a priori descriptions.

\section{Participants}

The participants were in-service English language teachers who work at English language preparatory schools in İstanbul. These instructors had Turkish, Middle Eastern and Western backgrounds. In the first phase of the research, the teachers were chosen according to purposive sampling which is regarded as the main feature of qualitative research (Cohen et. al., 2007). The teachers who met the scope of the research which is specifically English language teachers working at preparatory schools were selected. On the other hand, in the second phase of the research which was online interviewing, the teachers were chosen by volunteer sampling. It is used in cases where participants are interested in

\begin{tabular}{|c|c|}
\hline & \\
\hline aları $D$ & d Literatur \\
\hline $\mathrm{Mal}$ & Mahallesi, Mürver Çiçeği Sokak, No:14/8 \\
\hline Kadıköy & STANBUL / TURKEY 34714 \\
\hline $\begin{array}{r}\text { e-posta: edito } \\
\text { tel: }+905057958124,+\end{array}$ & $\begin{array}{l}\text { editor@rumelide.com, } \\
\text { +90 505 7958124, +90 } 216773 \text { o } 616\end{array}$ \\
\hline
\end{tabular}


taking part in the research study or happen to be interested from a course (Cohen et. al., 2007). In this study, the intercultural self-efficacy scale were sent to the teachers, and 42 participants completed the survey. The ones who would like to participate in the interview about their intercultural experiences took part in the interviews. 10 teachers who were from different countries and who had intercultural experiences were interviewed. We followed the necessary ethical procedures and obtained the participants' consents, providing them with the information about the study, and acknowledging their right to withdraw from the study at any time. We used the acronym IST for in-service teachers and gave them numbers to maximise confidentiality and anonymity.

\section{Data collection tools}

In the first phase of the research, data were collected through the Multicultural Efficacy Scale (MES) which was developed by Guyton \& Wesche (2005). The confirmatory factor analysis, and the reliability analysis that has resulted in Cronbach alpha of .83 point out that the MES has a good potential for researching the factors within the scale to be mentioned below. It was developed to measure the efficacy of language teachers in the multicultural education settings across the Unites States. Therefore, some changes have been made to adjust it to the purpose of the study which is to investigate English language teachers' intercultural self-efficacy beliefs and their intercultural experiences in the Turkish EFL context. The scale consists of 4 parts: instructors' intercultural experiences, attitudes towards diversity, intercultural self-efficacy beliefs and their strongest belief about intercultural language teaching. Attitudes or beliefs may not necessarily mean that the teachers apply them in their teaching practices. Therefore, the self-efficacy part of the survey can provide a better understanding of their prospect for teaching in an intercultural context, as efficacy has been indicated to be one powerful characteristic of successful teaching (Cochran-Smith, 1991; Zeichner, 1993).

In this mixed-methods study, with the aim of understanding in-service language teachers' both intercultural efficacy beliefs and intercultural experiences, online interviewing was used as a complementary instrument to the quantitative part to provide a richer and in-depth analysis. Volunteers took part in the online interviews about their intercultural experiences, and semistructured questions have been addressed to explore how they interpret cultural discourses, their interactions and language teaching practices. Interviews allow the participants to share their experiences and interpretations of the events from their point of view (Cohen et al., 2007: 349). Moreover, it makes it possible to learn what they think, value, and prefer. The interview has comprised semi-structured questions which could disclose their personal beliefs and prompt them to talk about their intercultural experiences, any problems they have faced, their beliefs on teaching diverse students and on working with diverse colleagues, and their intercultural teaching practices.

Prior to the interviews, two pilot interviews have been conducted to find out whether there is a need for changing the wording and to test the clarity of the questions. After the pilot interviews, we have added some follow-up questions to get more detailed answers from participants and asked the participants to engage with a narrative which reflects two prevailing concepts: 'individualism' and 'collectivism' discourses causing intercultural communication problems in the relationship of two friends from different cultural backgrounds. Another material which they looked at during the interviews was a reading and vocabulary lesson from an English language teaching coursebook. The topic of the reading was the stereotypical images of the West and the East. The reading text aimed at pushing the learners to think outside the box and look at the things from a big picture perspective. The text was basically a criticism of stereotypes. Thanks to the pilot interviews, we could make thick

\footnotetext{
\begin{tabular}{r|l} 
Adres & Address \\
RumeliDE Dil ve Edebiyat Araşttrmaları Dergisi & RumeliDE Journal of Language and Literature Studies
\end{tabular} Osmanağa Mahallesi, Mürver Çiçeği Sokak, No:14/8 $\quad$ Osmanağa Mahallesi, Mürver Çiçeği Sokak, No:14/8 Kadıköy - İSTANBUL / TÜRKIYE 34714 Kadıköy - ISTANBUL / TURKEY 34714 e-posta: editor@rumelide.com e-mail: editor@rumelide.com, tel: +90 505 7958124, +90 2167730616 phone: +90 505 7958124, +90 2167730616
} 
descriptions on the interviewees' approaches to culture, teaching practices, and stereotypical beliefs about other people who are different from them.

\section{Data analysis}

The scale about their intercultural experiences and self-efficacy beliefs was distributed via Google Forms to the instructors. The results were collected via Google Forms' Excel document. The percentage and the frequency of each item in the survey were calculated by Microsoft Excel. Moreover, all the online interviews were transcribed, and Braun and Clarke (2012) approach to thematic analysis was adopted in that data were systematically coded through reading and rereading. In this way, the responses for the questions were grouped, and possible generalisations were made through the constant comparison method (Miles and Huberman, 1994; Butler-Kisber, 2018). We compared the results of the survey with the interviews in that both have been complementary tools that broaden our insights into the research questions.

We have also drawn on three important principles for analysing the interviews through the lens of critical intercultural awareness: "put aside established descriptions; seek a broader picture; look for the hidden and unexpressed things" (Holliday, 2011 p. 27). Putting aside these dominant preoccupied ideas about cultural interactions through thick descriptions is essential for searching for the hidden and underlying meanings. Furthermore, critically uncovering the relationship between ideologies and intercultural discourses has been the key component throughout the data analysis.

\section{Results}

Results will be presented in two sections. First, as an answer to the RQ1, the results from the survey and from the interview questions related to in-class materials for intercultural language teaching will be explicated on to reveal the participants' intercultural experiences and self-efficacy beliefs. Then, a thicker description of their accounts of cultural identity and discourses influential in their intercultural exchanges will follow as an answer to the RQ2.

\section{EFL instructors' intercultural experiences and self-efficacy beliefs}

The frequential statistical data in Table 1 reveal that English language instructors' intercultural experiences mostly depend on the interactions with their students and colleagues. Besides, it is obvious that TV shows and movies are the other sources for their intercultural experiences.

Table 1. English language instructors' intercultural experiences

\begin{tabular}{lllll}
\hline & $\begin{array}{l}\text { neve } \\
\mathrm{r}\end{array}$ & $\begin{array}{l}\text { rarel } \\
\mathrm{y}\end{array}$ & $\begin{array}{l}\text { occasional } \\
\text { ly }\end{array}$ & $\begin{array}{l}\text { frequent } \\
\text { ly }\end{array}$ \\
\hline $\begin{array}{l}\text { Diverse people lived in my neighbourhood when I was a child growing } \\
\text { up. }\end{array}$ & $\begin{array}{l}26,2 \\
\%\end{array}$ & $\begin{array}{l}35,7 \\
\%\end{array}$ & 28,6 & $9,5 \%$ \\
$\begin{array}{l}\text { In the past, I chose to watch TV shows and movies about people } \\
\text { different from me. }\end{array}$ & $2,6 \%$ & $\begin{array}{l}17,9 \\
\%\end{array}$ & $33,3 \%$ & $46,2 \%$ \\
I interact with diverse students in my teaching context. & $4,8 \%$ & $9,5 \%$ & $28,6 \%$ & $57,1 \%$ \\
I share personal experiences with my diverse students. & $4,8 \%$ & $\begin{array}{l}26,2 \\
\%\end{array}$ & $38,1 \%$ & $31 \%$ \\
& $4,8 \%$ & $19 \%$ & $38,1 \%$ & $38,1 \%$
\end{tabular}


In my workplace, I interact with people different from me.

I share personal experiences with my diverse colleagues.

I share cultural experiences with my diverse colleagues.

$\begin{array}{llll}- & 9,5 \% & 38,1 \% & 52,4 \% \\ 2,4 \% & 19 \% & 45,2 \% & 33,3 \% \\ - & \begin{array}{l}28,6 \\ \%\end{array} & 38,1 \% & 33,3 \% \\ & & \end{array}$

The results are congruent with the follow-up interviews. The participants provided examples of their intercultural experiences related to their students and colleagues. In-service teacher (IST) 1 mentioned his intercultural experiences in diverse workplaces: "Most of the workplaces where I used to work, I had colleagues from different parts of the world as I worked in cosmopolitan cities such as Dubai, London and İstanbul.” Like IST1, IST9 explained his intercultural interactions with his colleagues: "Addressing people in a formal context (i.e., an office) changes from culture to culture, and nonTurkish colleagues might have problems about their existing habits in this new professional context. That's why I tried to help a colleague by explaining cultural differences in addressing people in such a context."

His views of culture reflected a comparison between cultural descriptions attributed to certain national groups as discrete and concrete entities. Nevertheless, his accounts also included the professional context as an example of 'small culture'. Likewise, IST7 exemplified her intercultural experiences at the university where she has worked, drawing on Centre and Periphery discourses with a distinction between 'native' and 'non-native' speakers: "I have colleagues who are native speakers of English and international students, most of whom are from the Middle East. So, I have teacher-student interactions with the students and professional interactions with colleagues. One of the colleagues is also my close friend."

Table 2 below illustrates English language instructors' attitudes towards diversity. It is striking that $73,8 \%$ of the survey participants strongly agree that classroom library should reflect different sociocultural and linguistic backgrounds. Moreover, 57,1 \% of the participants strongly agree that English language teachers are facilitators for students to share different sociocultural experiences, and coursebooks and textbooks should include cultural resources. More than half of the participants believe that English language teachers are to adapt lesson plans that reflect intercultural encounters. Congruent with the previously stated attitudes towards diversity, $42,9 \%$ of them do not agree that discussing ethnic traditions and beliefs at school leads to disunity and arguments between students from different cultural backgrounds. However, $42,9 \%$ of the participants do not think that including perspectives of diverse groups while teaching is essential.

Table 2. English language instructors' attitudes towards diversity

\begin{tabular}{lllll}
\hline & $\begin{array}{l}\text { agree } \\
\text { strongly }\end{array}$ & $\begin{array}{l}\text { agree } \\
\text { somewhat }\end{array}$ & $\begin{array}{l}\text { disagree } \\
\text { somewhat }\end{array}$ & $\begin{array}{l}\text { disagree } \\
\text { strongly }\end{array}$ \\
\hline $\begin{array}{l}\text { English language teachers should adapt lesson plans to } \\
\text { reflect the intercultural encounters between people. }\end{array}$ & $45,2 \%$ & $54,8 \%$ & & - \\
\end{tabular}

English language teachers should provide opportunities for students to share different sociocultural experiences.
$57,1 \%$

$9,5 \%$

$$
42,9 \%
$$

Discussing ethnic traditions and beliefs in school leads to disunity and arguments between students from different cultural backgrounds.

\section{Adres Address}

RumeliDE Dil ve Edebiyat Araşttrmalarn Dergisi Osmanağa Mahallesi, Mürver Ciiçeği Sokak, No:14/8 Kadıköy - ISTANBUL / TÜRKIYE 34714 e-posta: editor@rumelide.com tel: +90 $5057958124,+90216773$ o 616
RumeliDE Journal of Language and Literature Studies Osmanağa Mahallesi, Mürver Çiçeği Sokak, No:14/8

Kadıköy - ISTANBUL / TURKEY 34714

e-mail: editor@rumelide.com,

phone: +90 505 7958124, +90 216773 o 616 
A critical inquiry into in-service EFL teachers' intercultural self-efficacy beliefs and experiences / Z. G. Kani; S. Yllmaztürk (pp. 875-893)

It is essential to include the perspectives of diverse groups while teaching English.

Curricula and textbooks should include the contributions of most, if not all, cultural resources in our ELT context.

The classroom library should reflect different sociocultural and linguistic backgrounds.

$\begin{array}{llll}7,1 \% & 14,3 \% & 35,7 \% & 42,9 \% \\ 57,1 \% & 35,7 \% & 4,8 \% & 2,4 \% \\ & & & \\ 73,8 \% & 23,8 \% & - & 2,4 \%\end{array}$

In line with the presented data in Table 2, most of the participants talked about the importance of the teacher role and in-class materials for reflecting diversity. IST3 emphasised the interaction between university teachers and students- local or international: "As teachers, we should have some conversations, talk more about these cultural issues by means of speaking activities and reading texts. Additionally, foreign students and colleagues should share their experiences with the other students". Similarly, IST1 expressed the relationship between his previous intercultural experiences and his classroom practices: 'I share my own experiences of different cultures, the countries that I visited. I also put the students in multinational groups so that they can share different things with one another.' A nation-based view of culture was evident in his words.

IST4 also drew attention to the teacher role to encourage intercultural exchanges among students by group and pair work, and she especially highlighted the necessity of grouping in consideration of different nationalities:

When we have pair or group work activities, we should group them by choosing from different nationalities. Being partners with other nationalities is the advantage of diverse classes. They share the same language and learn from each other by finding common points, and they interact with each other. Interaction is the most important thing in language classrooms.

In addition to the role of teacher for promoting diversity, coursebooks and materials have been found as valuable resources in some of the interviews as well. According to IST6, the coursebook is a good choice to raise students' awareness on cultural issues: "There are some books that are deliberately dedicated to teaching cultural differences all around the world. It mostly depends on the coursebook." Some of the participants strongly believe that coursebooks are more than enough in language classes as IST2 asserted: “The materials that I have been using now are OK. The coursebook we are teaching has cultural issues, and it is more than enough. Especially, at this low level, the cultural issues in the coursebook are enough." However, IST7 does not believe that the coursebooks are culturally neutral and equal, and she highlights that it is not enough to solely depend on the course book: "Cultural resources are prepared from a highly essentialist perspective in the coursebook. I believe it promotes the domination of the Western countries with positive depictions. The book does not introduce other cultures extensively." Likewise, IST10 believes that many coursebooks are culturally bland and exemplifies the materials to be used to raise awareness on cultural issues as multinational media- TV, newspapers, and the Internet. IST5 also stated that while coursebooks seem enough, there is a need for more authentic materials such as scenes from TV series, films, some parts from newspapers to engage students in more real-like experiences.

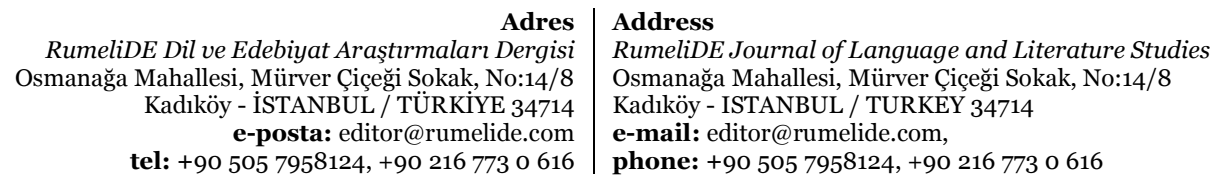

tel: $+905057958124,+902167730616$ e-mail: editor@rumelide.com,

phone: +90 5057958124, +90 2167730616 
When it comes to the English language instructors' self-efficacy beliefs about language teaching, a high percentage of participants are reported to believe that they could do these things reasonably well, as indicated in Table 3.

Table 3. English language instructors' intercultural self-efficacy beliefs

\begin{tabular}{|c|c|c|c|c|c|}
\hline & & $\begin{array}{l}\text { I do not believe I } \\
\text { could do this very } \\
\text { well }\end{array}$ & $\begin{array}{l}\text { I } \\
\text { coul } \\
\text { d } \\
\text { prob } \\
\text { ably } \\
\text { do } \\
\text { this } \\
\text { if I } \\
\text { had } \\
\text { to, } \\
\text { but } \\
\text { it } \\
\text { woul } \\
\text { d be } \\
\text { diffi } \\
\text { cult } \\
\text { for } \\
\text { me }\end{array}$ & $\begin{array}{l}\text { I } \\
\text { believ } \\
\text { e that } \\
\text { I } \\
\text { could } \\
\text { do } \\
\text { this } \\
\text { reaso } \\
\text { nably } \\
\text { well if } \\
\text { I had } \\
\text { time } \\
\text { to } \\
\text { prepa } \\
\text { re }\end{array}$ & $\begin{array}{l}\text { I am } \\
\text { quite } \\
\text { confi } \\
\text { dent } \\
\text { that } \\
\text { this } \\
\text { woul } \\
\text { d be } \\
\text { easy } \\
\text { for } \\
\text { me } \\
\text { to do }\end{array}$ \\
\hline \multicolumn{2}{|c|}{$\begin{array}{l}\text { I can provide instructional activities to help students to develop } \\
\text { strategies for dealing with intercultural encounters. }\end{array}$} & $7,1 \%$ & $\begin{array}{l}14,3 \\
\%\end{array}$ & $50 \%$ & $\begin{array}{l}28,6 \\
\%\end{array}$ \\
\hline \multicolumn{2}{|l|}{$\begin{array}{l}\text { I can adapt instructional methods to meet the needs of learners } \\
\text { from diverse groups. }\end{array}$} & $2,4 \%$ & $19 \%$ & $\begin{array}{l}47,6 \\
\%\end{array}$ & $31 \%$ \\
\hline \multicolumn{2}{|l|}{ I can develop materials appropriate for intercultural contexts. } & $4,8 \%$ & $\begin{array}{l}21,4 \\
\%\end{array}$ & $\begin{array}{l}47,6 \\
\%\end{array}$ & $\begin{array}{l}26,2 \\
\%\end{array}$ \\
\hline \multicolumn{2}{|l|}{$\begin{array}{l}\text { I can develop instructional methods that dispel myths about } \\
\text { diverse groups. }\end{array}$} & $16,7 \%$ & $\begin{array}{l}23,8 \\
\%\end{array}$ & $\begin{array}{l}45,2 \\
\%\end{array}$ & $\begin{array}{l}14,3 \\
\%\end{array}$ \\
\hline \multicolumn{2}{|c|}{$\begin{array}{l}\text { I can analyse instructional materials for potential stereotypical } \\
\text { and/or prejudicial content. }\end{array}$} & $7,1 \%$ & $9,5 \%$ & $50 \%$ & $\begin{array}{l}33,3 \\
\%\end{array}$ \\
\hline \multicolumn{2}{|l|}{ I can help students to examine their own prejudices. } & $2,4 \%$ & $\begin{array}{l}16,7 \\
\%\end{array}$ & $35,7 \%$ & $\begin{array}{l}45,2 \\
\%\end{array}$ \\
\hline \multicolumn{2}{|c|}{$\begin{array}{l}\text { I can present diverse groups in our society in a manner that will } \\
\text { build mutual respect. }\end{array}$} & $9,5 \%$ & $\begin{array}{l}21,4 \\
\%\end{array}$ & $\begin{array}{l}28,6 \\
\%\end{array}$ & $\begin{array}{l}40,5 \\
\%\end{array}$ \\
\hline \multicolumn{2}{|l|}{$\begin{array}{l}\text { I can develop activities that increase the self-confidence of } \\
\text { diverse students. }\end{array}$} & $4,8 \%$ & $\begin{array}{l}14,3 \\
\%\end{array}$ & $\begin{array}{l}45,2 \\
\%\end{array}$ & $\begin{array}{l}35,7 \\
\%\end{array}$ \\
\hline \multicolumn{2}{|l|}{$\begin{array}{l}\text { I can provide instruction showing how prejudice affects } \\
\text { individuals. }\end{array}$} & $11,9 \%$ & $7,1 \%$ & $\begin{array}{l}33,3 \\
\%\end{array}$ & $\begin{array}{l}47,6 \\
\%\end{array}$ \\
\hline \multicolumn{2}{|l|}{$\begin{array}{l}\text { I can plan instructional activities to reduce prejudice toward } \\
\text { diverse groups. }\end{array}$} & $4,8 \%$ & $\begin{array}{l}21,4 \\
\%\end{array}$ & $\begin{array}{l}52,4 \\
\%\end{array}$ & $\begin{array}{l}21,4 \\
\%\end{array}$ \\
\hline \multicolumn{2}{|l|}{$\begin{array}{l}\text { I can identify cultural biases in commercial materials used in } \\
\text { teaching. }\end{array}$} & $9,5 \%$ & $\begin{array}{l}2,4 \\
\%\end{array}$ & $\begin{array}{l}45,2 \\
\%\end{array}$ & $\begin{array}{l}42,9 \\
\%\end{array}$ \\
\hline \multicolumn{2}{|c|}{$\begin{array}{l}\text { I can help students work through problem situations caused by } \\
\text { stereotypical and/or prejudicial attitudes. }\end{array}$} & $11,9 \%$ & $7,1 \%$ & $\begin{array}{l}42,9 \\
\%\end{array}$ & $\begin{array}{l}38,1 \\
\%\end{array}$ \\
\hline \multicolumn{2}{|l|}{ I can get students from diverse groups to work together. } & $2,4 \%$ & $9,5 \%$ & $\begin{array}{l}47,6 \\
\%\end{array}$ & $\begin{array}{l}40,5 \\
\%\end{array}$ \\
\hline \multicolumn{2}{|l|}{ I can identify school practices that may harm diverse students. } & $4,8 \%$ & $\begin{array}{l}14,3 \\
\%\end{array}$ & $38,1 \%$ & $\begin{array}{l}42,9 \\
\%\end{array}$ \\
\hline \multicolumn{2}{|l|}{ I can identify solutions to problems that may arise as the result } & $7,1 \%$ & 14,3 & 52,4 & 26,2 \\
\hline $\begin{array}{r}\text { Adres } \\
\text { RumeliDE Dil ve Edebiyat Araşttrmaları Dergisi } \\
\text { Osmanağa Mahallesi, Mürver CCiçeği Sokkak, No:14/8 } \\
\text { Kadıköy - İTANBUL / TÜRKIYE } 34714 \\
\text { e-posta: editor@rumelide.com } \\
\text { tel: +990 505 7958124, +90 } 216773 \text { o } 616\end{array}$ & $\begin{array}{l}\text { Address } \\
\text { RumeliDE } \\
\text { Osmanağa } \\
\text { Kadıköy - } \\
\text { e-mail: ec } \\
\text { phone: + }\end{array}$ & $\begin{array}{l}\text { ournal of Language and I } \\
\text { Iahallesi, Mürver Çiçeği S } \\
\text { TANBUL / TURKEY } 3471 \\
\text { tor@ rumelide.com, } \\
5057958124,+9021677\end{array}$ & $\begin{array}{l}\text { ture Stuc } \\
\text { No: } 14 / 8\end{array}$ & & \\
\hline
\end{tabular}


A critical inquiry into in-service EFL teachers' intercultural self-efficacy beliefs and experiences / Z. G. Kani; S. Yılmaztürk (pp. 875-893)

of diversity.

I can identify the societal forces which influence opportunities for diverse people.

I can identify ways in which various groups contribute to our society.

I can help students understand the perspective of ethnic and cultural groups different from their own.

I can help students view history and current events from diverse perspectives.

I can involve students in making decisions and clarifying their values regarding intercultural issues.

\begin{tabular}{|c|c|c|}
\hline 6 & $\%$ & $\%$ \\
\hline $\begin{array}{l}23,8 \\
\%\end{array}$ & $38,1 \%$ & $31 \%$ \\
\hline $9,5 \%$ & $\begin{array}{l}54,4 \\
\%\end{array}$ & $\begin{array}{l}28,6 \\
\%\end{array}$ \\
\hline $\begin{array}{l}11,9 \\
\%\end{array}$ & $38,1 \%$ & $\begin{array}{l}45,2 \\
\%\end{array}$ \\
\hline $9,5 \%$ & $57,1 \%$ & $\begin{array}{l}26,2 \\
\%\end{array}$ \\
\hline $7,1 \%$ & $\begin{array}{l}45,2 \\
\%\end{array}$ & $\begin{array}{l}40,5 \\
\%\end{array}$ \\
\hline
\end{tabular}

One of the striking points in the table is that most of the teachers $(57,1 \%)$ think that they can help their students view historical and current events from diverse perspectives if they had time to prepare. Another important point is that $54,4 \%$ of the participants have reported to identify the ways in which various groups contribute to the society. Similarly, more than fifty percent of them believe that they can plan instructional activities to reduce prejudice toward diverse groups, and that they can identify solutions to the problems that may arise because of diversity. Moreover, half of the participants believe that they can provide instructional activities to help their students to develop strategies for dealing with intercultural encounters, and they can analyse instructional materials for potential stereotypical and/or prejudicial content. Overall, English language teachers are quite confident about including intercultural issues in their teaching practices.

In the interviews, some of the participants have talked about the problems which they have faced in diverse classes and the ways which they have dealt with them. IST1 mentioned a problem that he had faced in a groupwork task: "Sometimes, some students do not accept to work with students from specific nationalities. They do not feel close to each other. I do not push them to work together. If I push them, I know that they might hate each other. Therefore, in some tasks, I try to find some common things." IST6 also stated a cultural problem that he had faced: "For some countries, it is not okay for girls and boys to sit together. They bring that culture with them to the classroom, and they decide not to sit close to other people. Especially, girls don't sit with boys. I was able to force them to do the activity for a few weeks, but after some time they did not want to do that."

Some of the participants talked about stereotypical information and concluded that it is necessary to see the things from another side, or with a different perspective. These recommendations are in line with the findings of the survey. To exemplify, IST5 mentioned some of her friends' stereotypical views about her home country, Turkey. It was believed to be a part of the Eastern world and was viewed with full of wrong information. This made her uncomfortable, and she tried to correct the things they generalised to all the people living in that country. Because of that, during the lessons she preferred to talk about stereotypes and let students think about whether they were true for everybody or not. Moreover, IST3 from a Western society, who regarded culture as a discrete national entity, narrated how she underwent a change in her views after coming to Turkey:

Every culture is different, and it is hard to deal with it in the beginning, but in time, you can get along with it. I faced a cultural shock. No matter how prepared you are to that new culture, you may find a lot of things you have not expected. I came with a lot of beliefs about Turkey because of media. I was thinking Turkey would be preservative, but I found out that it was closer to Western culture. I have changed my beliefs with my own experiences, by living in Turkey, and spending time.

\footnotetext{
Adres $\mid$ Address

RumeliDE Dil ve Edebiyat Arașttrmaları Dergisi Osmanağa Mahallesi, Mürver Ciçeği Sokak, No:14/8 Kadıköy - ISTANBUL / TÜRKIYE 34714 e-posta: editor@rumelide.com tel: +90 505 7958124, +90 2167730616

RumeliDE Journal of Language and Literature Studies Osmanağa Mahallesi, Mürver Çiçeği Sokak, No:14/8

Kadıköy - ISTANBUL / TURKEY 34714

e-mail: editor@rumelide.com,

phone: +90 505 7958124, +90 2167730616
} 
As for the part about their strongest belief about intercultural teaching as in Table 4, two of the given statements were among the most significant beliefs. First and foremost, nearly half of the participants viewed cultural differences as a resource rather than an explaining structure or a set of restricting rules. In addition to seeing cultural differences as a resource, a high percent of the participants reported the necessity of respecting individual differences to diminish intercultural problems.

Table 4. The major purpose of intercultural teaching

\begin{tabular}{llc}
\hline & Percentage & Frequency \\
\hline $\begin{array}{l}\text { If every individual learned to accept and work with every other person, then } \\
\text { there would be no intercultural problems. }\end{array}$ & $33,3 \%$ & 14 \\
$\begin{array}{l}\text { If cultural differences are viewed as a resource rather than an explaining } \\
\text { structure or a set of confining structures, there would be a harmony in the } \\
\text { society. }\end{array}$ & $42,9 \%$ & 18 \\
$\begin{array}{l}\text { All cultural groups are entitled to maintain their own identity. } \\
\begin{array}{l}\text { All cultural groups should be recognized for their strengths and } \\
\text { contributions. }\end{array}\end{array}$ & $9,5 \%$ & 4 \\
$\begin{array}{l}\text { Some groups need to be helped to achieve equal treatment before we can } \\
\text { reach the goals of a democratic society. }\end{array}$ & $\mathbf{2 , 4 \%}$ & $\mathbf{1}$ \\
\hline \begin{tabular}{l} 
Total \\
\hline
\end{tabular} & $\mathbf{1 0 0 \%}$ & 42 \\
\hline
\end{tabular}

In complementary to the survey, the interview data obtained through their engagement with a narrative have also contributed to thick description regarding the survey choices of the participants and broadened our knowledge about their perspectives on cultural issues in relation to real-life experiences in intercultural settings and regarding cultural discourses.

\section{EFL instructors' accounts of culture, identity, and communication}

The interviews consisted of the semi-structured questions, a narrative regarding an intercultural exchange between two people representing the West and the East, and in-class materials related to intercultural settings. The story and the materials which the participants reflectively engaged with prompted more insights into their real-life experiences as they expanded on their views of culture and cultural identity in this way. Cultural complexity and discourses of 'collectivism' and 'individualism' were the most outstanding themes that describe their real-life experiences of interculturality and cultural identity.

\section{Cultural complexity}

The participants were asked to define how they view culture and their cultural identities, and cultural complexity emerged as one of the main themes out of the interviews. The sub-themes which were evident in their accounts of the complex and subtle process of developing their cultural identities are "the fluidity of culture, contextual variables, changing realities from context to context and from time to time, the role of religion and of nation in their cultural identities, and their interplay with culture."

Drawing on her experiences in different countries, IST3 acknowledged that her interactions with people from different cultural backgrounds contributed to her understanding of culture. She drew attention to the blurred lines among cultural spaces and overall contextual variables, which affected

\begin{tabular}{r|l} 
Adres & Address \\
RumeliDE Dil ve Edebiyat Araştırmalar Dergisi & RumeliDE Journal of Language and Literature Studies \\
Osmanağa Mahallesi, Mürver Çiçeği Sokak, No:14/8 & Osmanağa Mahallesi, Mürver Çiçeği Sokak, No:14/8 \\
Kadıköy - İSTANBUL / TÜRKIYE 34714 & Kadıköy - ISTANBUL / TURKEY 34714 \\
e-posta: editor@rumelide.com & e-mail: editor@rumelide.com, \\
phone: +90 505 7958124, +90 2167730616
\end{tabular}


A critical inquiry into in-service EFL teachers' intercultural self-efficacy beliefs and experiences / Z. G. Kani; S. Yllmaztürk (pp. 875-893)

her cultural identity. It may be inferred from her response that cultural realities change from context to context and from time to time, and so is her cultural identity:

It is shaped through my life experiences and affected by my interactions with different nationals. I've learnt to accept more. I don't think that I will be surprised and shocked by any other culture anymore. Turkey is a very good experience because here I saw how people respect each other, and how things are smooth although there are differences. You feel like everyone is respecting one another, which is not the case in a European country I have been to. They do not accept differences that much. I try to understand and accept any culture.

As obvious in her words, she could establish empathy with the cultural groups in the periphery and sought for ways to understand local people's sensitivities, which could result from the fact that she was caring for the others and that she wanted to be accepted by others at the same time. She may have felt more attachment or closeness to the country she lived in now as a member of a 'non-western' context. While IST3, from a Middle Eastern background, had a view of culture enclosed within geographical and national boundaries, she associated some values such as openness and willingness to accept differences with a specific country, Turkey, in comparison to Europe. She was critical of the 'Western' cultural discourse as she identified:

"Western" does not mean all the time good things like civilization, and modernity. When you learn about other cultures, for example, minorities' cultures, you get more interested in them. I love them more. I accept them more. I understand how much we are small in this space. All these experiences define my culture. Nation's role in my cultural identity is about the way of respecting. When you are in a new country, you learn what annoys people and what touches their ego.

Like IST3, IST1 also asserted that his cultural identity was dynamic and heterogenous. His intercultural experiences seemed to affect his cultural identity, although he prioritised the role of nation and history over his experiences in the make-up of his background: "Culture is what is inherited from the ancestors, the mixture of history and geography. My cultural identity is somehow mixed. I have to admit that I have a strong background, but I am flexible, too. I am an international citizen, so it means I have an international culture. Nation also plays a great role.”

IST6 attributed a great role to nation as well. Nevertheless, in addition to what the previous participants emphasised, he mentioned the role of education and religion in his cultural identity. It might be concluded from his response that nationality, religion together with his experiences and interactions shaped his cultural identity:

Your cultural identity is your nationality, your religion, your education, and your family. It is the people you hang out with because in a long term they're going to influence the way you think and behave. I would say cultural identity is affected by almost anything you read, you see, you hear. And nationality absolutely. Religion plays a very important role here. The more educated you are, the more broad-minded you are in terms of cultural differences.

IST5 thought along the same lines as IST6 and highlighted the role of nation too. However, she also mentioned that she was affected by the Centre countries' cultural artefacts and instances because of her English language learning experiences:

My culture is Turkish culture. Nation plays a great role in my culture, and my nationality is not an individualist one. Everything and everybody are connected to each other. There is a chain reaction. However, once I start learning English, my perspective on culture has changed in a way. I was listening to English songs, watching TV series and movies in English. Everything I have done to learn English has contributed to my culture. I believe that there are cultural differences, and that it is something good. You also find similarities between them, so you can be a part of that society or

\begin{tabular}{r|l} 
Adres & Address \\
RumeliDE Dil ve Edebiyat Araşttrmaları Dergisi & RumeliDE Journal of Language and Literature Studies \\
Osmanağa Mahallesi, Mürver Çiçeği Sokak, No:14/8 & Osmanağa Mahallesi, Mürver Çiçeği Sokak, No:14/8 \\
Kadıköy - İSTANBUL / TÜRKIYY 34714 & Kadıöy - ISTANBUL / TURKEY 34714 \\
e-posta: editor@rumelide.com & e-mail: editor@rumelide.com, \\
tel: +90 505 7958124, +90 2167730616 & phone: +90 505 7958124, +90 216773 o 616
\end{tabular}


culture. Similarities and differences are important while communicating. They give you clues about the context of the conversation, and about the people you are going to talk to.

Different from other participants, IST2 specified the huge impact of his religion on his cultural identity, whereas he did not find nation as influential as religion:

It is a mixture of Arabian and Middle Eastern. This is me. I am also open minded because of spending three years in America. I saw how people are dealing with each other, but I am a Muslim after all. I care much about my religion. That is why I am much affected by this. Religion is important in my culture identity. My nation plays some role in my culture identity but not as much as religion.

IST7, on the other hand, suggested that while nation is indispensable part of her culture, her experiences and education shaped her cultural identity. It was clear that she felt a belonging to several cultural realities at the same time:

I can't ignore the impact of my nationality on my identity. The place I was born into and the family I was raised in are the essentials of my identity. However, the education I received and the realities I discovered by myself made me who I am today. I might not be the same person in the future as I am not the person who I was in the past. Culture is not restricted to geographical boundaries. Within myself, I am a member of many cultures. Therefore, differences are inevitable, and respect is a must to live peacefully.

IST10 did not place his cultural identity under any of the previously mentioned categories. He defined it in a more unique point of view. Similar to IST5, he believed that differences are a resource for interactions:

I treat "my culture" with humour and parody, as I try to do with all cultures even at the risk of offending those who take such things seriously. For me, an important part of university education and, indeed, of life-education is to learn and teach how to look at things from different perspectives. I also believe cultural differences are usually a good source of debate and discussion and humour.

In addition to the participants' accounts of culture, identity and intercultural communication, there was another recurrent theme that emerged out of their reflection on the critical narrative during the interviews: 'individualism' and 'collectivism' discourses.

\section{Individualism and collectivism}

More than half of the participants related 'individualism' to Centre, Western, and European countries, while Eastern countries were reported to be 'collectivist'. This essentialist discourse was evident in IST2's accounts:
Individualism is related to European and American cultures. They are not the same as the Middle Eastern communities that are collectivist. The west is individualist. In fact, I was much affected by the Western culture because I travelled to America when I was young. At the same time, I am also affected by my own religion. That's why when I turned back to Egypt, I got married and started a family. I cannot say that I am one hundred percent western. I am western only in the decision that are connected to my own life and business. Before making a decision, I have to consult my family. This is the good part.

While the West has been associated with taking decisions on one's own, IST5 identified her home country as one of the 'collectivist' countries, and she stated that she was happy with being a part of a 'collectivist' society from time to time. Approaching the terms in a more critical way than the others, IST3 rejected the association of the West with positive things such as modernity, civilization, technology:

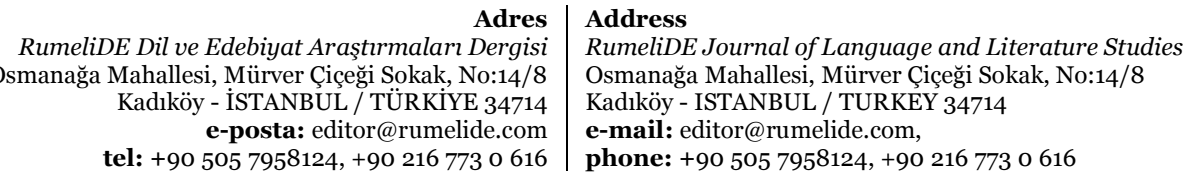


A critical inquiry into in-service EFL teachers' intercultural self-efficacy beliefs and experiences / Z. G. Kani; S. Yllmaztürk (pp. 875-893)

Individualism is having your own choices, decision, and it is being autonomous, while collectivism is being a part of group, and sharing with other people. I see it from the point of capitalism and socialism. You cannot be completely individualist or collectivist. We shouldn't lean on one side. Many people believe the strong division of west and non-west. They all the time see the west, civilization, modernity, technology, improvement, and then comes the non-west. It is thought that what comes from the west is modern, but it is not always true. The west world says: "You need development, knowledge. I am from the west, and I can provide them to you." It caused colonisation. It is another word for colonisation. They used it as an excuse for colonisation. "Get rid of your culture, and identity!", they say.

These extracts displayed how the extent to which the participants' views of these cultural discourses differ in terms of criticality. Their views could be considered to have been shaped through their process of developing a self through their exploration of cultural realities, artefacts, arenas, and interactions as detailed in the previous section.

\section{Discussion and conclusion}

The findings of the study on the intercultural beliefs and experiences of in-service English language teachers at universities showed that they frequently interacted with their diverse colleagues and students, and that they shared their personal and cultural experiences with each other. Their intercultural experiences were also formed by TV and movies. In the interviews, they all mentioned their experiences in different countries and the ways they were affected by their interactions and experiences in these countries. People they met, their lifestyles, the institutions where they worked, and their colleagues shaped their understanding of culture. These participants emphasised being respectful and willing to communicate with diverse people, accepting diversity, discussing the different and the unknown, and displaying humour in their accounts of such experiences. These features have been regarded as a part of having intercultural competence which have also been shown to increase through communication with diverse people and as a sign of being international in the studies by Beutel and Tangen (2018), Demircioğlu \& Çakır (2015), Hayden et al. (2000), Lin (2018), Smolcic \& Arends (2017), and Polat and Ogay-Barka (2014), who explored the perspectives of pre-service or inservice teachers' intercultural learning. These teachers showed cultural self-awareness, awareness of the complexity of cultural identity, empathy, and emerging critical cultural awareness and supported intercultural language teaching in terms of awareness raising.

In the present study, we also found that a high percentage of the participants showed positive attitudes towards the inclusion of diversity and intercultural exchanges. Curricula, coursebooks, and the classroom library were found important to represent such diversities and cultural differences. The role of the teacher to provide these opportunities was also emphasised both in the interview and in the survey. Moreover, the participants were reasonably confident in raising intercultural awareness and dealing with the diversity in their teaching practices as found in the studies by Atay et al. (2009), Kaça (2015) and Çubukçu (2013). Nevertheless, due to the time and curriculum limitations, there was a discrepancy between their beliefs about their capability to provide, analyse, adapt and develop instructional activities and methods to help students to develop strategies for dealing with intercultural encounters and stereotypical or prejudicial content and their practices as in the studies by Sercu (2005; 2006), Oranje and Smith (2018), and Young and Sachdev (2011).

During the interviews, they highlighted that teachers play a crucial role in providing intercultural communication. One of the striking conclusions from the interviews was that teachers especially put students in groups with those who are culturally different from each other to make them interact with diverse classmates in English. Another conclusion drawn from the survey was that a high percentage of

RumeliDE Dil ve Edebiyat Araşttrmaları Dergisi Osmanağa Mahallesi, Mürver Ciçeği Sokak, No:14/8 Kadıköy - İSTANBUL / TÜRKIYE 34714 e-posta: editor@rumelide.com tel: +90 $5057958124,+902167730616$
Address

RumeliDE Journal of Language and Literature Studies

Osmanağa Mahallesi, Mürver Çiçeği Sokak, No:14/8

Kadıköy - ISTANBUL / TURKEY 34714

e-mail: editor@rumelide.com,

phone: +90 $5057958124,+902167730616$ 
English language teachers thought that the purpose of intercultural language teaching is viewing cultural differences as a resource rather than a restricting structure and aimed at incorporating these differences in their classroom practices with a variety of in-class and extracurricular activities.

The findings from the interview also displayed that culture had a complex dimension and that nation played a great role in most of the participants' cultural identities. A variety of elements such as religion, education, family, ancestors, history, and experiences were reported to form the cultural identities of the participants. Some of them mentioned that they belonged to several cultural realities. In conclusion, many of them perceived cultural realities not confining but emergent and expressive as suggested by Holliday (2011; 2016), Kramsh (2013) and Yulita (2013). Nevertheless, when the dichotomous terms of individualism and collectivism were considered, their opinions differed in that while some of the participants associated them with the positivist perspective, which perceives West as the best and as symbolic of civilisation and individualism, some of the participants did not relate these terms to any countries. Their intercultural experiences paved the way for looking from a 'small culture formation on the go' perspective (Holliday, 2013: 56), while they were under the influence of prevailing national or other structures at the same time.

Overall, the study presented a critical and in-depth analysis of how university EFL teachers of diverse backgrounds approached the interplay between language teaching and the discourses of the intercultural, with the focus on their intercultural self-efficacy beliefs, reported practices, and experiences. It contributed to a 'decentred' understanding of cultural issues through the eyes of these key actors of the language classroom as one of emergent, overlapping and interacting 'small cultures', where local praxes and discourses may have more impact than national or international ones.

\section{Implications}

The study provided several implications for researchers who investigate cultural issues such as identity, intercultural communication, and intercultural language teaching from a critical interpretivist perspective. Theoretically, they can also draw on a critical perspective of culture as fluid, dynamic, heterogenous and complex, and offer more insights into cases of teacher and student groups in different parts of the world. Methodologically, they can go beyond the mainstream competency-based studies and use a mixed-methods design, employing several prompters such as a narrative, and course materials to effectively engage with teachers' reflection on real-life experiences in various contexts. Further small-scale studies into the in-class experiences of teachers and students in diverse course designs could also yield fruitful interpretations and implementations for promoting more teacherconstructed practical theory.

\section{References}

Altan, M. Z. (2018). Intercultural sensitivity: A study of pre-service English language teachers. Journal of Intercultural Communication, 46, 1-17.

Arcagök, S., and Yılmaz, C. (2020). Intercultural sensitivities: A mixed methods study with pre-service EFL teachers in Turkey. Issues in Educational Research, 3O(1), 1-18.

Atay, D., Kurt, G., Çamlıbel, Z., Ersin, P., \& Kaslıoğlu, Ö. (2009). The role of intercultural competence in foreign language teaching. İnönü University Journal of the Faculty of Education, 1O(3),123135 .

Baker, W. (2011). Intercultural awareness: Modelling an understanding of cultures in intercultural communication through English as a lingua franca. Language and Intercultural Communication, 11(3), 197-214.

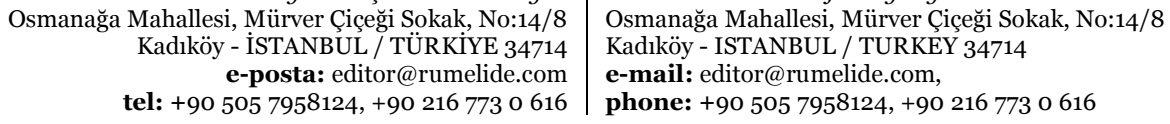


A critical inquiry into in-service EFL teachers' intercultural self-efficacy beliefs and experiences / Z. G. Kani; S. Yılmaztürk (pp. 875-893)

Beutel, D. A., \& Tangen, D. (2018). The Impact of intercultural experiences on preservice teachers' preparedness to engage with diverse learners. Australian Journal of Teacher Education, 43(3), 168-179.

Braun, V., \& Clarke, V. (2012). Thematic analysis. In H. Cooper (Ed.), The handbook of research methods in psychology (pp. 57-71). Washington: American Psychological Association.

Butler-Kisber, L. (2018). Qualitative inquiry: Thematic, narrative and arts-based perspectives (2nd Edition). London: Sage.

Cohen, L., Manion, L., \& Morrison, K. (2007). Research Methods in Education. London: Routledge.

Cochran-Smith, M. (1991). Learning to teach against the grain. Harvard Educational Review, 61(3), 279-310.

Çetin-Köroğlu, Z. (2016). Measuring English language teacher candidates' intercultural sensitivity: A key element to foster intercultural communicative competence. International Online Journal of Education and Teaching (IOJET), 3(1). 43-52.

Çubukçu, F. (2013). Pre-service English teachers' intercultural sensitivity. International Journal of Human Sciences, 10, 832-843.

Demircioğlu, S.., \& Çakır, C. (2015). Intercultural competence of English language teachers in International Baccalaureate World Schools in Turkey and abroad. Journal of language and linguistic studies, 11(1), 15-32.

Dyer, C. (1995). Beginning research in psychology. Oxford: Blackwell.

Ersoy, A. (2013). Turkish teacher candidates' challenges regarding cross-cultural experiences: The case of Erasmus exchange program. Education and Science, 38, 155-166.

Geertz, C. (1973). The interpretation of cultures: Selected essays. New York, NY: Basic Books.

Guyton, E. M., \& Wesche, M. V. (2005). The Multicultural efficacy scale: Development, item selection, and reliability. Multicultural Perspectives, 7(4), 21-29.

Hayden, M., Rancic, B., \& Thompson, J. (2000). Being international: student and teacher perceptions from international schools. Oxford Review of Education, 26(1), 107-123.

Holliday, A. (1999). Small cultures. Applied Linguistics, 20, 237-264.

Holliday, A., Hyde, M., \& Kullman, J. (2010). Intercultural communication: An advanced resource book for students. Oxon: Routledge Applied Linguistics.

Holliday, A. (2011). Intercultural communication and ideology. London: SAGE.

Holliday, A. (2013). Understanding intercultural communication: Negotiating a grammar of culture. London: Routledge.

Holliday, A. (2016). Difference and awareness in cultural travel: Negotiating blocks and threads. Language and Intercultural Communication, 16(3), 318-331.

House, J. (2002). Developing pragmatic competence in English as a lingua franca. In Knapp K. \& Meierkord C. (Eds.), Lingua franca communication (pp. 245-267). Frankfurt am Main: Peter Lang.

Israelsson, A. (2016). Teachers' perception of the concept of intercultural competence in teaching English (Unpublished master's thesis). Stockholm University, Stockholm, Sweden.

Kaça, E. (2015). Teachers' beliefs and practices of cultural content in the ELT classroom: A multifaceted analysis through the EIL lens (Unpublished master's thesis). Middle East Technical University, Northern Cyprus Campus, Kalkanlı-Güzelyurt, Turkish Republic of Northern Cyprus.

Keranen, N., \& Bayyurt, Y. (2006). Intercultural Telecollaboration: In-service EFL teachers in Mexico and pre-service EFL teachers in Turkey. TESL-EJ, 1O(3), 1-50.

\begin{tabular}{r|l} 
Adres & Address \\
RumeliDE Dil ve Edebiyat Araşttrmaları Dergisi & RumeliDE Journal of Language and Literature Studies \\
Osmanağa Mahallesi, Mürver Çiçeği Sokak, No:14/8 & Osmanağa Mahallesi, Mürver Çiçeği Sokak, No:14/8 \\
Kadıköy - ISTANBUL / TÜRKIYE 34714 & Kadıköy - ISTANBUL / TURKEY 34714 \\
e-posta: editor@rumelide.com & e-mail: editor@rumelide.com, \\
phone: +90 505 7958124, +90 2167730616
\end{tabular}


Kirkpatrick, A. (2007). World Englishes: Implications for international communication and English language teaching. Cambridge: Cambridge University Press.

Kramsch, C. (2013). Culture in foreign language teaching. Iranian Journal of Language Teaching Research, 1(1), 57-78.

Lázár, I. (2011). Teachers' beliefs about integrating the development of intercultural communicative competence in language teaching. ForumSprache, $5,113-128$.

Liddicoat, A. J., \& Scarino, A. (2013). Intercultural language teaching and learning. Oxford, England: Wiley Blackwell.

Lin, M. (2018). "I don't even know where Turkey is.": Developing intercultural competence through epal exchanges. Journal of Global Education and Research, 2(2), 68-81.

Miles, M. B., \& Huberman, A. M. (1994). Qualitative data analysis: An expanded sourcebook (2nd Ed.). Thousand Oaks, CA: Sage.

Newton, J., Yates, E., Shearn, S., \& Nowitzki, W. (2010). Intercultural communicative language teaching: Implications for effective teaching and learning. Wellington, New Zealand: School of Linguistics and Applied Language Studies.

Nugent, K., \& Catalano, T. (2015). Critical cultural awareness in the foreign language classroom. NECTFL Review, 75, 15-30.

Oranje, J. L., \& and Smith, L. F. (2018). Language teacher cognitions and intercultural language teaching: The New Zealand perspective. Language Teaching Research, 22(3) 310-329.

Phipps, A. M., \& Guilherme, M. (2004). Critical pedagogy: Political approaches to language and intercultural communication. Clevedon: Multilingual Matters.

Polat, S. \& Barka, T. O. (2014). Preservice teachers' intercultural competence: A comparative study of teachers in Switzerland and Turkey. Eurasian Journal of Educational Research, 54, 19-38.

Sercu, L. (2005). Foreign language teachers and intercultural competence: An international investigation. Clevedon, England: Multilingual Matters.

Sercu, L. (2006). Foreign language teachers and intercultural competence teaching. International Journal of Applied Linguistics, 151, 15-32.

Smolcic, E., \& Arends, J. (2017). Building teacher interculturality: Student partnerships in university classrooms. Teacher Education Quarterly, 44(4), 51-73.

Türkylmaz-Sinclair, S. (2019). A case study exploring the intercultural sensitivity levels of native English and native Turkish language instructors teaching at universities in Turkey and the U.S.A. respectively (Unpublished master's thesis). İhsan Doğramacı Bilkent University, Ankara, Turkey.

Witte, A. (2014). Blending spaces: Mediating and assessing intercultural competence in the L2 classroom. Boston, MA: De Gruyter.

Young, T. J., \& Sachdev, I. (2011). Intercultural communicative competence: exploring English language teachers' beliefs and practices. Language Awareness, 2O(2), 81-98.

Yulita, L. (2013). Critical pedagogy: Stereotyping as oppression. In S. Houghton, Y. Furumura, M. Lebedko, \& S. Li (Eds.), Critical cultural awareness: Managing stereotypes through intercultural (language) education (pp. 204-220). Newcastle upon Tyne, U.K.: Cambridge Scholars Publishing.

Zeichner, K. M. (1993). Educating teachers for cultural diversity. East Lansing, MI: National Center for Research on Teacher Learning. 